\title{
ROMANS, ROADS, AND ROMANTIC \\ CREATORS: TRADITIONS OF PUBLIC \\ PROPERTY IN THE INFORMATION AGE
}

\author{
CAROL M. ROSE*
}

I

INTRODUCTION

In a recent publication, the historian Paul Greenough addresses what he describes as the "standard environmental narrative" ("SEN") about the relationships between people and the forest in southern Asia-a narrative that casts the local forest-dwellers of the past as something akin to keepers or caretakers of the forest. Greenough observes that when he encounters this generic and romantic "SEN," he always wants to know where the wild animals are. 'Wildlife may seem thrilling and attractive to those who do not have to contend with it, but in the nineteenth century colonial Indian subcontinent, the animals of the forest were in constant battle with the villagers. The villagers thrived when the tigers and elephants were at bay, and they were horrified and demoralized when these creatures flourished, trampling crops and devouring the village women who carried firewood home from the woods. Indeed, when the wildlife gained sufficient ground, the villagers sometimes abandoned their homes, which were reclaimed by the trees and vines and their animal inhabitants. ${ }^{2}$

One might surmise that people who hold intellectual property rights have much the same attitude about the public domain that South Asian villagers once had about the jungle: Like the jungle and its beasts, the public domain threatens to overrun them at every turn. Try as they might to cultivate their little properties, their patents and copyrights expire, their secrets get found out, their trademarks come into general usage, and all these erstwhile possessions return to the wild of the public domain, where the savage creatures indiscriminately gobble up everything. Incidentally, people who have carved

Copyright (C) 2003 by Carol M. Rose

This article is also available at http://www.law.duke.edu/journals/66LCPCarolRose.

* Gordon Bradford Tweedy Professor of Law and Organization, Yale Law School.

For their very helpful comments on earlier drafts, I would like to thank James Boyle, Arthur Campbell, Rochelle Dreyfus, and Kenji Yoshino, as well as the participants at the law faculty workshops at New York University and California Western, and of course, the Duke Symposium on the Public Domain.

1. Paul Greenough, Naturae Ferae: Wild Animals in South Asia and the Standard Environmental Narrative, in AgARARIAN STUDIES: SYNTHETIC WORK AT THE CUTTING EDGE 141, 141-147 (James C. Scott \& Nina Bhatt eds., 2001).

2. Id. at $12-20$. 
out niches in the public lands of the United States seem to have much the same attitude about the more tangible version of the public domain: They are always at risk of being gobbled up by its environmental laws, its threats of increased grazing fees, and its newly-declared National Monuments and Roadless Areas. ${ }^{3}$

Both in such tangible spaces and in the "spaces" of intellectual endeavor, it is intriguing that the raging wildness of the public domain has so many champions. Is this simply a matter of ignoring the cultivated spaces of the villagers and leaving them to their fate? Or is there something positive to be said for these wild spaces in their own right?

No doubt, one ground for a favorable view of the public domain in what I will call "Intellectual Space" is simply that the positive arguments for exclusive property rights are so much thinner here than they are in what I will call "Tangible Space." It is widely thought that, with respect to tangible matters, two forceful Utilitarian arguments support exclusive property. The first is that exclusive property rights prevent wasteful overuse of resources and stave off the much-discussed "Tragedy of the Commons" that often accompanies open access. ${ }^{4}$ The second is that exclusive property encourages optimal investment in resource development, since the gains and losses from that investment come back to the owner. ${ }^{5}$

In Intellectual Space, the first of these familiar arguments falls away, since there is no physical resource to be ruined by overuse. Books, tapes, and words may be copied, inventions may be imitated, pictures may be reproduced-all without the slightest damage to the original. Hence the Utilitarian case for exclusive rights in Intellectual Space rests entirely on the second argument, that the grant of exclusive property encourages appropriate investment in creativity. To be sure, there are non-Utilitarian arguments for intellectual property rights too, particularly claims based on labor or personality, but these are shared to a large degree with property in tangible resources. The long and short of it, then, is that exclusive property rights come up long in Tangible Space but rather short in Intellectual Space. This means that although there is still a case for property in the intellectual realm, the commons or the public domain is relatively more thinkable.

In this paper, I am going to leverage this point of the comparative advantage of publicness in Intellectual Space. To do so, I will turn to the other side, to Tangible Space, to ask whether there is a case to be made even here for the public domain. One would think that if the public domain is at all attractive in

3. For a tempered but sympathetic view of related grievances, see A. Dan Tarlock, Can Cowboys Become Indians? Protecting Western Communities as Endangered Cultural Remnants, 31 ARIZ. ST. L.J. 539 (1999).

4. For both propositions, see 2 William Blackstone, COMMENTARIES $* 3-* 8$ (describing humanity's early use of resources in common, leading to waste, leading to the creation of property to encourage investment); for a more modern version, see RICHARD A. POSNER, ECONOMIC ANALYSIS OF LAW 30 (3d ed. 1986) (similar points but stressing investment, citing Blackstone). The tragedy derives from Garrett Hardin, The Tragedy of the Commons, SCI., Dec. 13, 1968 at 1243.

5. BLACKSTONE, supra note 4 , at $* 7$. 
Tangible Space, where there is such a strong argument to the contrary based on the potential waste of resources, then the arguments for the public domain should be even more compelling in Intellectual Space, where the counterarguments for exclusivity are cut in half.

Ultimately, I will conclude that to some degree this surmise is true-that the arguments for the public domain are more persuasive in Intellectual Spacebut the examination of "publicness" in Tangible Space reveals a number of considerations and limitations, some of which carry over into Intellectual Space. I am going to work through those considerations by reflecting on a very old body of thought, namely the Roman law's categories of nonexclusive property. ${ }^{6}$ Anything that I say here should be taken, as the Romans said, cum grano salis, because I am at best a novice both in Roman law and in matters of intellectual property. All the same, I will suggest that the Roman law's reasons for the "publicness" of some tangible property might carry some weight in the intellectual realm as well-but so do some of the Roman law's limitations and qualifications on the "publicness" of property.

Unfortunately for the public domain, much of the interest in nonexclusive property began to melt away from Western legal thinking by the seventeenth century, a phenomenon that the legal historian Daniel Coquilette has ascribed to the growing visibility of the enclosure movement. ${ }^{7}$ As Coquillette points out, Grotius cast doubt on whether some of the older Roman legal categories of nonexclusive property could really be called property at all, ${ }^{8}$ and two centuries later, the American James Kent could observe that what was called "common property" was rapidly vanishing from American law."

These developments displaced an earlier tradition of legal thought about nonexclusive property in the Roman law, as it was compiled and interpreted through the centuries. To be sure, the surviving sources of the Roman law did not develop the various types of nonexclusive property at any great length. ${ }^{10}$ Moreover, the distinctions in the classical texts themselves seem "rather fluid," as one Roman law scholar delicately put it. ${ }^{11}$ Nevertheless, the range of the accepted Roman law categories of nonexclusive property do at least give us a glimpse of a variety of concerns-concerns that are often blithely lumped together as "the commons" in our own legal and economic thinking.

6. Some others have also turned to the Roman law in analyzing aspects of intellectual property, though in a somewhat different way. See, e.g., Russ VerSteeg, The Roman Law Roots of Copyright, 59 MD. L. REV. 522 (2000) (finding Roman law doctrines implicit in the private property of copyright).

7. Daniel R. Coquillette, Mosses from an Old Manse: Another Look at Some Historic Property Cases about the Environment, 64 CORNELL. L. REV. 761, 807-809 (1979).

8. Id. at 807 .

9. Id. at 807 n. 223 .

10. Id. at 801-803.

11. William. W. BUCKLAND, A TEXT-BOOK OF ROMAN LAW FROM AUGUSTUS TO JUSTINIAN 184 (rev., 3d ed., 1963); $c f$. ROBERT W. LEE, THE ELEMENTS OF ROMAN LAW: WITH A TRANSLATION OF THE INSTITUTES OF JUSTINIAN 109 (4th ed. 1956) (remarking of the classical distinctions, "[a]ll this is very confused"). 
Because these categories seem "fluid" even to scholars who know much more than I do about these historical matters, I will give a somewhat stylized version of the Roman law classes of nonexclusive property, along with the reasons why that body of law treated different classes of property as open to the public. Although the Roman law itself appears to have been quite relentlessly concerned with tangible property and not at all with intellectual property, ${ }^{12}$ I will try to tease out applications and analogies to arguments for the public domain in the intellectual realm.

What follows, then, is a rough typology of nonexclusive property under the Roman law-its applications and limitations in the realm of tangible things, and the analogies and contrasts that might be drawn in the realm of intellectual achievements.

\section{II}

\section{RES NULLIUS: THINGS BELONGING TO NO ONE}

Aside from religious objects (of which more later), this first category of res nullius consists of things that are not by their nature nonexclusive; they have simply not yet been appropriated by anyone. ${ }^{13}$ Fish and game animals are frequent examples in the literature, as is abandoned property and, interestingly and perhaps horribly, enemy property. With all these resources, the reduction of the "thing" to exclusive property is simply a matter of human desire, time, and effort-and nonexclusive property simply results from the lack of those qualities with respect to the thing in question. ${ }^{14}$ In the United States, a much larger example lies in the public lands of the West as they existed up until the closing of the range in $1934 .{ }^{15}$ Although these lands officially belonged to the United States, until that time they were effectively open for the taking, aside from often ignored Indian claims. By 1934, the areas that people considered the most valuable for mines, agriculture, forestry, water development, and other uses had already been appropriated. What was left behind to the supervision of what became the vastly overextended Bureau of Land Management ("BLM") were those lands that the settlers considered worthless, or at least as more trouble than they were worth-res nullius, it seemed, and likely to stay that way. ${ }^{16}$ By the present, of course, attitudes about BLM lands have changed dramatically, and people now want to use these often strikingly austere and beautiful lands for everything from grazing to mining to dune-buggying to white-water rafting. Controversies rage over whether parts or all of these lands should be appropriable, and for what. Indeed, they would be appropriable for

12. VerSteeg, supra note 6, at 523-24.

13. BUCKLAND, supra note 11 at 184; WiLliam A. HUNTER, INTRODUCTION TO ROMAN LAW 5960 (rev., 9th ed., 1934).

14. HUNTER, supra note 13 , at 60.

15. George Cameron Coggins et Al., Federal Public Land And Resources Law 133-34 (4th ed. 2001).

16. Id. at $133-34,139,142-43$. 
almost anything, if we still considered them res nullius, and if we continued to ignore the prior claims of Native Americans.

What about ideas and expressions and inventions in their undiscovered or un-created state? Insofar as they are open to the public, might they be res nullius, things simply awaiting appropriation? To a degree, yes, insofar as someone might use secrecy to keep exclusive use of some invention or discovery. Secrecy, however, is difficult to maintain in many intellectual endeavors, and since one cannot "appropriate" intellectual matters in any other ways in the natural world, it is difficult to class them with the appropriable-butnot-yet-appropriated things of res nullius. Hence, one might more easily see most intellectual matters as falling within the next Roman law category, to wit:

III

\section{RES COMMUNES: THINGS OPEN TO ALL BY THEIR NATURE}

Res communes encapsulates what might be called the Impossibility Argument against private property: The character of some resources makes them incapable of "capture" or any other act of exclusive appropriation.

Before coming to intellectual matters, let us first consider res communes in tangible things, as the Roman lawyers did. The usual Roman law examples of res communes resources were the oceans and the air mantle, since they were impossible for anyone to own. ${ }^{17}$ Though the Roman lawyers did not say much about them, modern environmentalists might add the stocks of wild animals and fish - that is, wildlife stocks as opposed to individual wild specimens, which of course can be captured. Some wild stocks are indeed small and localized enough to be susceptible to common ownership by fishing communities, as in the well-known lobster fishing grounds around Monhegan Island. ${ }^{18}$ But taken as wholes, many wildlife and fishing stocks are like the air or the oceans, in that they seem too wide ranging and diffuse for exclusive possession-whale stocks span the oceans, butterflies and hummingbirds cross continents.

Like the air and the open waters, however, such large and dispersed stocks are ultimately finite, and their seeming limitlessness only makes them more vulnerable to overhunting, overfishing, or pollution. ${ }^{19}$ The English common law, while much influenced by Roman law, may have been more sensitive to the potential congestibility and exhaustibility of running water and fish stocks and air. Hence the English did assert that there was a kind of ownership or at least general supervision of such things through larger political institutions. To use Blackstone's language, in order to avoid the "disturbances and quarrels [that] would frequently arise" about such matters, the common law "wisely cut up the

17. HUNTER, supra note 13 , at 65 .

18. See generally JAMES M. ACHESOn, THE LOBSTER GANGS OF MAINE (1988) (describing island fishing grounds and their governance).

19. H. Scott Gordon, The Economic Theory of a Common-Property Resource: The Fishery, 62 J. POL. ECON. 124 (1954); see also JAMES R. MCGOODWIN, CRISIS IN THE WORLD's FISHERIES 61-64 (1990) (describing heavy decimation of open access fish stocks in modern era). 
root of dissension, by vesting the things themselves in the sovereign of the state." ${ }^{20}$ In the twentieth century, some nation-states have extended this pattern, claiming the resources of the ocean waters at least out to a twohundred-mile limit.

In the last decade, we have seen a much more dramatic turn in the "propertization" of what might seem to be "un-ownable" diffuse resources or res communes in the tangible world. Since 1990, the United States has treated the air itself as national property, capping the air's use for certain types of pollution and then granting individually-held Tradeable Environmental Allowances ("TEAs") for limited pollution rights. Other countries, notably Australia and New Zealand, have adopted similar programs for limited but tradeable individual rights in portions of certain fish stocks. ${ }^{21}$ As with intellectual property rights, the major objective of TEAs appears to be the encouragement of appropriate levels and directions of investment. When polluters have to buy TEAs, they may think about investing in prevention instead, and when fishers must buy fishing allotments, they may think about using their boats for something other than fishing. ${ }^{22}$

Currently, TEAs are in force only in very limited spheres, despite the enormous theoretical interest in them. Putting aside the political problems, it is still too expensive and complicated to work out tradeable rights in most complex ecosystem resources. ${ }^{23}$ But this does not prevent calls for more. Tradeable rights have been discussed for new types of fisheries, wildlife habitat, and air pollutants (notably greenhouse gases), despite thorny questions about whether the ecosystem services derived from one set of resources can make up for losses in another.

These developments in property rights suggest that while the "impossibility argument" for res communes still has some force in Tangible Space, innovations in the law are chipping away at it. Governmental advances in measurement, record-keeping, and legal enforcement have allowed things once thought incapable of ownership to become ownable after all.

Now, what about Intellectual Space? Even more than air, water, or fisheries, intellectual achievements seem closely aligned to the Roman law idea of res communes as things incapable of ownership. Some inventions, of course,

20. Blackstone, supra note 4 , at $* 14, * 15$. Blackstone mentioned here inter alia "waste" lands and game animals.

21. See Carol M. Rose, Expanding the Choices for the Global Commons: Comparing Newfangled Tradable Allowance Schemes to Old-Fashioned Common Property Regimes, 10 DUKE ENVTL. L. \& POL'Y F. 45, 51 (1999) (comparing TEAs to community based property).

22. Id. at 60. Aside from payment, TEAs do little in themselves to induce their holders to avoid overuse, since the holders of TEAs still have incentives to cheat on their individual allotments. The policing of overuse instead generally falls on the governments that enforce and monitor the overall system of rights.

23. Thomas W. Merrill, Explaining Market Mechanisms, 2000 U. ILL. L. REV. 275, 285, 296-98 (2000) (describing the small number of market-based environmental programs, attributing this to combination of cost and political obstacles); James Salzman \& J. B. Ruhl, Currencies and the Commodification of Environmental Law, 53 STAN. L. REV. 607, 622-27 (2000) (describing difficulties of "nonfungibilities" in ecosystem trades). 
may be "owned" through secrecy, and indeed, one of the objects of intellectual property law is to induce inventors to disclose secrets so that others may build on their ideas. But inventive secrets, especially commercially valuable ones, have long been subject to the intense scrutiny of rivals, and every successful feat of reverse engineering makes the invention slip further away from the inventor's exclusive grasp. ${ }^{24}$ Moreover, secrecy is particularly ill suited to another main preoccupation of intellectual property, the protection of expressions, since secrecy would generally defeat the expression itself. ${ }^{25}$ It is in this sense that intellectual matters seem akin to res communes: The inventor, and even more the artist, may have only limited ability to keep exclusive control over her achievements.

But what can give her that control is intellectual property law itself. Hence, in intellectual matters as in environmental ones, advances in legal thought and governmental administration undermine the "impossibility argument" at the foundation of res communes. Preliminarily, one might even say that the function of intellectual property is to turn res communes, things by their nature incapable of ownership, into res nullius, things not yet owned but capable of appropriation.

Indeed, legal regimes go further than this: Appropriation via intellectual property presumably adds to social well-being by creating appropriate incentives to invest in creative ideas. But in a development worrisome to many, private parties now use law to go beyond the more constrained private rights of intellectual property. Instead, some have deployed contract law to erect more far-reaching property-like barriers on intellectual products, as in the shrinkwrap contracts of software packaging. ${ }^{26}$

What about cyberspace? Could the ease of copying on this medium set up a last holdout for res communes, an arena where exclusive property is truly impossible? Some scholars argue that it could, because cyberspace is supposedly too vast and diffuse for its information flows to yield even to government management, much less to private ownership. ${ }^{27}$ Yet here too, res communes may be somewhat open to doubt. Other scholars of cyberspace argue that growing legal and governmental capacities will permit something like ownership in many areas. ${ }^{28}$ Indeed, when some members of the Clinton

24. Pamela Samuelson \& Susan Scotchmer, The Law and Economics of Reverse Engineering, 111 YALE L. J. 1575, 1577 (2002).

25. Some religious ceremonies and ceremonial arts, however, are kept secret because they can be undermined by publicity. See Christine Haight Farley, Protecting Folklore of Indigenous Peoples: Is Intellectual Property the Answer? 30 CONN. L. REV. 1, 14-15 (1997) (arguing that some indigenous peoples resist publicity for religious art).

26. Mark Lemley, Beyond Preemption: The Law and Policy of Intellectual Property Licensing, 87 CAL. L. REV. 111 (1999) (attacking current contract law as bypassing public rights that are embedded in intellectual property law). See, e.g., ProCD v. Zeidenberg, 908 F.Supp. 640 (W.D. Wis. 1996).

27. See David R. Johnson \& David Post, Law and Borders-The Rise of Law in Cyberspace, 48 STAN. L. REV. 1367, 1370-78, 1390-91 (1996) (arguing that governments cannot control cyberspace).

28. Lawrence Lessig, The Zones of Cyberspace, 48 STAN. L. REV. 1403, 1408-09 (1996) (disputing the argument that cyberspace cannot be controlled). 
Administration proposed a number of extensions of intellectual property into cyberspace, the ensuing heated exchange suggested that, whatever the wisdom of the policy of propertization, it is at least possible that patent and copyright law can spread property well into the digital world. ${ }^{29}$ Subsequent legislation has only made that fact more obvious. ${ }^{30}$

From all appearances, then, it seems that the impossibility argument behind res communes cannot be the only support for the public domain in intellectual matters. Hence, it should not be any surprise that the current arguments for the public domain in Intellectual Space necessarily go beyond the simply naturalistic and become normative as well. Are there analogies to such normative arguments in Tangible Space? Yes, there are, and once again they are reflected in another Roman law category of nonexclusive property-one that is particularly salient to modern questions of intellectual endeavor and hence meriting a somewhat lengthy treatment:

IV

\section{RES PUBLICAE: THINGS BELONGING TO THE PUBLIC AND OPEN TO THE PUBLIC BY OPERATION OF LAW}

\section{A. Res publicae in Tangible Space}

The classic examples of res publicae for Roman law were roads, harbors, ports, bridges, rivers that flowed year-round, and lands immediately adjacent thereto. $^{31} \quad$ Apparently this category was frequently mixed up with res communes, ${ }^{32}$ just as in more modern times we tend to mix up normative arguments for "publicness" with naturalistic arguments about the impossibility of owning certain resources. What is the normative case for holding such properties open to the public? As Richard Epstein has pointed out, the case for holding property open to the public is stronger where there is little danger of overuse and where little investment is required, as in ocean lanes. ${ }^{33}$ Some examples of res publicae do seem to fall into this category, such as some waterways and their shorelines. Nevertheless, other examples of res publicae, such as roads, harbors, and bridges, are clearly subject to congestion and overuse and require investment.

Low levels of congestibility and modest needs for investment, then, cannot be the only explanation for res publicae. Moreover, this normative category of inherently public property was not just a quirk of Roman law, but a concept

29. See Pamela Samuelson, The Copyright Grab, WIRED MAG., Jan. 1996, at 134 (opposing copyright extensions in digital communications).

30. See Maureen Ryan, Cyberspace as Public Space: A Public Trust Paradigm for Copyright in a Digital World, 79 OR. L. REV. 647, 670-74 (2001) (describing recent intellectual property legislation).

31. BUCKLAND, supra note 11, at 183; HUNTER, supra note 13, at 65-66; ANDREW BORKOWSKI, TEXTBOOK ON ROMAN LAW 143 (1994).

32. See BORKOWSKI, supra note 31, at 144 (describing seashores).

33. Richard A. Epstein, On the Optimal Mix of Private and Common Property, in PROPERTY RIGHTS 17, 27-28 (Ellen Frankel Paul et al. eds., 1994). 
with continuing vitality in Western law. If anything it became most firmly fixed in our own United States, this most commercial of all republics, where one would suppose that the arguments for publicness would be steadfastly rejected. Nevertheless, the normative claims of publicness run like a red thread (yes, that kind of red) through our law, most strikingly in the continuing idea of a "public trust" in resources that very closely resemble the major examples of res publicae in Roman law. ${ }^{34}$ Those resources are overwhelmingly the physical spaces required for mobility-lanes for travel, transportation, navigation, and communication among distant locations. ${ }^{35}$ For the Romans, such spaces were initially developed into res publicae primarily for military reasons ${ }^{36}$ but for Americans, they came to serve as the backbone of commerce itself.

What are the characteristics that call for publicly-protected open access to such spaces? In the past there were several, and at least in the American law of "inherently public" property, they have had to exist in combination. The first characteristic is what economists call "transaction costs." Travel lanes like roads and waterways are typically long and thin, ${ }^{37}$ and hence they are vulnerable to many possibilities for obstruction and bottlenecks, where any one of multiple miscreants or opportunistic adjacent owners can effectively take control of the whole length of the road. If the public is to use such ways, they may well require the protection of public officers or judges against these multiple threats of obstruction. ${ }^{38}$ In a way, the problem for res publicae in Tangible Space is not that its appropriation is impossible, but rather that it is all too easy to appropriate.

But why should the public have open access to these otherwise appropriable properties, particularly in light of the ever-lurking threat of congestion, overuse and underinvestment in tangible things that are open to the public? This brings in the second and especially critical factor-the presence of wide-ranging synergies, or what are now called network effects. Nineteenth century courts located the center of the "publicness" of travel lanes in their suitability for commerce, but commerce itself is endlessly synergistic. Commerce permits and encourages specialization, and in so doing, wider commerce exponentially enhances the value of all parties' property: One can invest in one's property not

34. The modern locus classicus for the public trust concept is Joseph L. Sax, The Public Trust Doctrine in Natural Resource Law: Effective Judicial Intervention, 68 MICH. L. REV. 471 (1970) (describing public trust doctrine in U.S. law). See also Coquillette, supra note 7, at 809-820.

35. Carol M. Rose, The Comedy of the Commons: Custom, Commerce, and Inherently Public Property, 53 U. CHI. L. REV. 711, 774 (1986) [hereinafter Rose, Comedy]; see also Carol M. Rose, Joseph Sax and the Idea of the Public Trust, 25 ECOLOGY L.Q. 351, 359-60 (1998) (describing centrality of commerce in public trust idea).

36. See T. W. Potter, Roman Italy 130 (1987) (describing Roman road system as having primarily military significance, though noting also commercial uses, as in the Via Salaria, an important route in the salt trade).

37. See Lakeside Park Co. v. Forsmark, 153 A.2d 486, 487 (Pa. 1959) (describing navigable and hence public water as a long, thin "roadway of water" that joins communities).

38. See Rose, Comedy, supra note 35, at 749-50 (noting that potential monopolization was one rationale for public claims to roads and waterways; noting also the similarity to eminent domain rationales). 
only for one's own use, but for the use of the person in the trading community who most values it. The greater the network of trade, the larger the market, the greater the opportunities for specialization, and the better for all participants. ${ }^{39}$

Traders have typically needed physical routes for transportation, and even though there may be congestion costs to those routes, there are ever-larger offsetting gains. The costs of congestion and overuse increase only arithmetically as lanes of trade are more widely used. While these costs must indeed be managed (a point to which I will return), the social benefits from the ensuing trade are exponential, and thus on the routes of res publicae, the more the merrier. Communication is similar. Consider the telephone network: As with other communications networks, the larger this network is, the more valuable it is for all participants, and the more the cross-fertilization of ideas can lead to still more ideas.

A related synergistic factor has to be teased out of American public trust law. This factor derives from the idea that commerce can play an educative and civilizing role. Republican theory at least as far back as Montesquieu and the Scottish Enlightenment suggested that commerce is "gentle," softening manners that would be hardened by the aristocratic characteristics of honor and pride. ${ }^{40}$ Commerce instead requires that the participants pay attention to the wants and desires of their counterparts, and in learning to do so, they perforce learn to work with others and become interested in and sympathetic to people whom they might otherwise disdain. ${ }^{41}$ There is, indeed, a whole panoply of arguments that commerce constitutes the social glue of democratic self-governance-for example, that property and trade are a school for rights-consciousness, that commerce deflects people from ideological enmity, and that commerce teaches us to operate by consent rather than force. ${ }^{42}$

Some of these arguments are more convincing, some less so, and some may seem odd when we often hear the worst aristocratic vices-callousness, brutality, grandiosity-associated with business and its "robber barons." Nevertheless, there is evidence from modern historians and experimental psychologists, among others, that trading relations can indeed turn into philanthropy, mutual aid, and what is now sometimes called social capital. ${ }^{43}$ If we think of commerce in this light - as contributing to the political synergies of democratic self-governance-then it is not an accident that public claims on tangible property spilled over from the roads of commerce to public squares

39. Id. at 769-771 (describing combination of holdout and interactivity as prerequisites for public trust claims, particularly with respect to commercial lanes).

40. Albert Hirschman, THE PASSIONS AND THE INTERESTs 55-60 (1977).

41. Id.; Rose, Comedy, supra note 35, at 775-76.

42. Carol M. Rose, Property as the Keystone Right?, 71 Notre DAME L. REV. 329, 348-51, 354-55 (1996).

43. See Francis fukuyama, Trust: The Social Virtues and the Creation of PROSPERITY (1995) (describing commercial relations in several countries, their influence on social capital); Peter Kollock, The Emergence of Exchange Structures: An Experimental Study of Uncertainty, Commitment, and Trust, 100 AM. J. SoC. 313, 337-39 (1994) (reporting positive mutual attitudes of subjects in successful simulated trade relations). 
and to other places for public speech and political communication. ${ }^{44}$ It is not an accident that the lanes of travel, transportation, communication, and commerce are called res publicae, the very root of the republic. And finally, perhaps it is not an accident that attacks on the transportation system seem to strike the republic at its core.

Two caveats are in order about res publicae, however. The first is that res publicae is far from an untamed place, where "anything goes." On the contrary, precisely because of the potential problems of congestion and underinvestment, the public in res publicae must behave in an orderly fashion. Nineteenth century case law gave a clear picture of a public that was subject to customary rules of usage, and today's users of roads, highways, and waterways on the whole continue to vindicate that picture. The expectation was, and is, that drivers would move to the right to avoid oncoming traffic; that sailors would try to avoid fishermen's nets; that travelers who had to leave the road to avoid obstructions would take the closest and least damaging route through the adjacent private property. ${ }^{45}$ In short, one is expected to behave one's self in the spaces of res publicae.

On the whole, however, the customary norms relevant to res publicae are relatively thin, and they can suffice to keep order only at very minor levels of congestion. Greater congestion may require road signs, harbor development, traffic management, lighthouses, air traffic control, piracy policing-any of which may easily surpass the capacity of a public that governs itself by informal norms alone. For that reason, we have to call on organized government to keep the spaces of res publicae in order. This was true for the Romans as well; it is no wonder that the Roman law's examples of res publicae included a large number of goods supplied and financed by organized governments. ${ }^{46}$ The vision of the public domain in res publicae is tame rather than wild, more like a park than a wilderness, a set of public spaces most often overseen by organized public institutions.

A second caveat: The concept of res publicae was by no means antagonistic to private property. The two combined elements in res publicae are synergistic effects, taken together with the possibility of monopoly. There are many arenas in which synergistic effects give rise to public concern-for example, in health and education-but in which no particular input resources might generate holdout or bottleneck, and hence little worry about monopolistic private ownership of the relevant inputs. Even where bottleneck or monopoly does loom, as in railroads or ferryboats or airlines, private entities may still own the relevant resources, subject to requirements of reasonable public access. Indeed, if the public is otherwise adequately served, the concept of res publicae may

44. Rose, Comedy, supra note 35 , at $753,778$.

45. Id. at 744-45.

46. POTTER, supra note 36, at 134 (stating that road maintenance was primarily at public expense); cf. id. at 82-83 (describing private finance of municipal baths and theaters by wealthy persons vying for political office and influence). 
present no obstacle to additional private properties of the same kind-toll roads and the like-without much additional governmental supervision.

The most important point, however, is that the idea of res publicae works hand in glove with a regime in which most resources are the subject of private property. Indeed, open public access to commercial lanes would make little sense without an underlying regime of private property and trade. The openness of trade routes presumes that the users of these routes have their own incentives to trade, and that those incentives come in large part from private ownership.

\section{B. The Internet as Res publicae}

All this brings me to the counterparts to res publicae in Intellectual Space. The closest analogies clearly lie in modern telecommunications, and perhaps especially in the Internet. The roads and waterways of the tangible and traditional res publicae allowed goods and information to flow freely, and the Internet does the same; here ideas can cross-fertilize one another in wonderful synergies of creativity. ${ }^{47}$ Indeed, the Internet even has the name "information superhighway," though that moniker now sounds slightly dated.

Looking at the Internet as the most obvious example of res publicae in Intellectual Space, let us take up the first of the caveats about the traditional res publicae, namely the question of governance. The res publicae in tangible property is a park and not a wilderness; but what about the Internet? Clearly the Internet is also not an arena where "anything goes." It has its protocols, its webmasters, its internal governance to repress vandals and promote orderly flows of information. But need this governance come from formal government, or are informal or customary norms enough? Recall that in the traditional res publicae, the need for formal governance comes in large part because there may be physical congestion and physical overuse of resources; some organized body must put up the traffic light and fix the potholes. On the Internet, problems of physical infrastructure and overcrowding are less apparent. Even though one's email inbox can indeed be loaded with spam, voluntary efforts and thin norms may possibly suffice to provide whatever governance and investment we need to keep lanes more or less clear. ${ }^{48}$

If voluntary self-organization suffices, the Internet as res publicae may be more like the informal roads of the nineteenth century American countryside,

47. See, e.g., Margaret Chon, New Wine Bursting from Old Bottles: Collaborative Internet Art, Joint Works, and Entrepreneurship, 75 OR . L. REV. 257, 274 (1996) (describing Internet's chain art).

48. Johnson \& Post, supra note 27, at 1388-91 (arguing that cyberspace users can develop internal norms); $c f$. Llewellyn Joseph Gibbons, No Regulation, Government Regulation, or Self-Regulation: Social Enforcement or Social Contracting of Governance in Cyberspace, 6 CORNELL J. L. \& PUB. POL'Y 475, 520-23 (1997) (noting lack of homogeneity and multi-dimensional contacts that might generate thick norms, but noting other technological and social factors in policing behavior); Margaret Jane Radin, Property Evolving in Cyberspace, 15 J.L. \& COM. 509, 516 (1996) (suggesting that thicker norms might have been more characteristic of "early cyberspace" when users were less numerous and more homogeneous). 
where customary practices seemed to be enough to enforce good behavior. Still, that story suggests that with more users, greater congestion, more vandalism and the like, more formal institutions might ultimately be required to take over what was formerly a "People's Park." And, as others have noted, more formal governance raises questions about the democratic character of the governmental institutions that might come to manage the Internet, for example what constraints they might put on information, or what issues of privacy they might encounter. ${ }^{49}$ Many of the ancient Romans may not have had much to say about their government's management of res publicae, but we do about ours. ${ }^{50}$

The second caveat about the tangible res publicae concerned its relation to private property. The Internet as res publicae, like the transportation routes of old, has a more complicated relationship to private property than simply posing a public realm against a private one. In his article in this symposium, James Boyle describes the new efforts to expand intellectual property as a second enclosure movement. ${ }^{51}$ It is important to point out, however, that the public domain-or res publicae itself, in the form of extended transportation-was critical to the first enclosure movement. Transportation improvements in the early modern period integrated England into a more unified market; this integration in turn fostered agricultural specialization and enclosure while undermining the older, more localized and mixed economies of the common fields. ${ }^{52}$ Similarly today, the greater opportunities for copying and disseminating via the Internet-the new res publicae-may well have engendered the new efforts towards "enclosure." Many intellectual accomplishments once needed no "fences" because they were difficult to copy, but they are now available to the world through digital access and reproduction. It is this dramatically enhanced new res publicae of digital communication that raises the demand for a much-extended fencing in of intellectual property. Thus, if we are now seeing a second enclosure movement, we might think that, as in the first enclosure movement, the enhancement of the public domain of communications itself has been deeply implicated in the efforts toward private enclosure.

This is not to say that the new privatization efforts reflect sound policy; far from it, as many of the articles in this symposium illustrate. But the more general lesson is that it is a mistake to suppose that the public domain and

49. This is not to say that there are no issues of democratic governance in informal norms. See infra notes 73-75 and accompanying text (concerning problems of informal norms).

50. Democratic control of formal government could even make formal government more attractive than community customs. See Carol M. Rose, Common Property, Regulatory Property and Environmental Protection, in THE Drama of THE COMMONS 233, 251-53 (Elinor Ostrom et al. eds., 2002) (noting antidemocratic characteristics of some community customs, rejection of customary law in United States in favor of formal laws passed by representative governments).

51. See James Boyle, The Second Enclosure Movement and the Construction of the Public Domain, 66 LAW \& CONTEMP. PROBS. 33 (Winter/Spring 2003).

52. See Carl J. Dahlman, The Open Field System And Beyond: A Property Rights ANALYSIS OF AN ECONOMIC INSTITUTION 106-108, 167-68 (1980) (noting poor transportation as a factor in older localized agriculture, improved transportation as part of economic integration and demise of common field system); see also id. at 145-59 (describing the importance of regional specialization in enclosure movement). 
private property are independent realms. Instead, the two are intimately intertwined, both historically and economically.

\section{Intellectual Space Generally as Res publicae?}

Turning from the Internet itself as res publicae, what about the content of materials flowing over the Internet? Might the whole realm of intellectual endeavor be considered res publicae? If one looks to the most important feature of res publicae, the synergies that are fostered by openness to the public, the answer seems obvious: Of course there are synergies in the intellectual world. It is widely known that creators develop their ideas in part from perceiving the ideas of others. Several scholars have criticized intellectual property law for its "romantic" and unrealistic conception of the sole, heroic individual author or inventor. ${ }^{53}$ Scientific innovators are often described as "standing on the shoulders of giants," ideas leave off and another's begin is often impossible to discern. But more than that, the interactions among creators can deliver something that is vastly more than the sum of their individual efforts. Scholars of literature even have a word for this (and one sometimes borrowed by intellectual property scholars): "intertextuality," where one literary text "converses" with others, and the conversation itself is more than the sum of the parts. ${ }^{55}$ The same can be said for philosophic texts: Witness Kant's famous reaction to his unsettlement upon reading Hume's views on causation. ${ }^{56}$ Thus the whole of Intellectual Space, in a sense, seems to be a candidate for treatment as res publicae, things open to the public by operation of law, because of the synergies among ideas.

Synergies alone, however, are not enough to make the case for res publicae. The other factor is transaction costs-the possibility of obstructions. If intellectual accomplishments are by their nature non-rivalrous and not easily possessed, there should be no obstruction or transaction costs to their synergistic exchange aside from the ability of creators to keep secrets, generally a doubtful proposition over the long run. Intellectual accomplishments could be safely left as res communes (things incapable of ownership); desirable synergies should occur without the legal protection supplied for res publicae.

53. See James Boyle, Shamans, Software and SpleEns: LAW AND THE Construction of THE INFORMATION SOCIETY 56-57 (1996); see also MARK ROSE, AUTHORS AND OwNERS: THE INVENTION OF COPYRIGHT, 125-28 (1993) (describing and criticizing the idea of creative genius); Rosemary J. Coombe, Left Out on the Information Highway, 75 OR. L. REV. 237, 246 (1996) (noting contributions in artwork of many unacknowledged persons).

54. Letter from Sir Issac Newton to Robert Hooke, Feb. 5, 1675 in 1 THE CORRESPONDENCE OF ISAAC NEWTON 416 (Herbert W. Turnbull ed., 1959).

55. See George Kamberelis, Genre as Institutionally Informed Social Practice, 6 J. CONTEMP. LEGAL ISSUES 115, 130-32 (1995) (describing literary theories of intertextuality). For Internet scholars' borrowing, see, for example, Chon, supra note 47, at 264-65 (applying idea of "intertext" to Internet).

56. Immanuel Kant, Prolegomena to Any Future Metaphysics 5-6 (Paul Carus trans., Bobbs-Merrill 1950) (1783). 
Instead, such obstructions as exist seem to come from law itself, sometimes in the direct form of censorship, but much more pervasively in the indirect form of intellectual property law. If intellectual property rights always and ineluctably blocked other intellectual efforts, the answer would seem obvious: Call off intellectual property, allow the realm of ideas to return to a happy state in which the synergistic interactions of res publicae are married to the ungoverned res communes - ungoverned, because, by their nature, ideas and information are freely available to all.

The mere fact of private ownership, however, does not mean that interactions are blocked. On the contrary, in Tangible Space, it is generally thought that well-defined property rights make interactions more possible, through the vehicle of trade. ${ }^{57}$ At least some of Intellectual Space looks the same. Clearly, people buy patent rights and pay copyright royalties all the time, and they have invented a variety of methods to reduce the transaction costs of doing so. ${ }^{58}$ More importantly, property rights, taken together with trade, should result in an even greater spread of ideas than would occur if intellectual matters were res communes. In the very standard theory, property rights give people an incentive to create innovations in the first place, and then to offer them freely on the market instead of keeping them secret, since they know that they can take the proceeds from trade.

As in Tangible Space, this argument is subject to qualifications: Transaction costs may still arise, a matter very common in a regime of intellectual property. At the extreme, a proliferation of multiple intellectual property rights can cause an "anticommons," paralyzing further research or creative endeavors. ${ }^{59}$ For such blockages, res publicae does apply, because here synergies are threatened by private appropriation; the res publicae analogy suggests such doctrines as mandatory licensing or "fair use," granting limited public access during the term of the intellectual property right. ${ }^{60}$

Nevertheless, it is important to recall that second caveat about res publicae: At least in its traditional domains, this is not a concept that is hostile to private property. Instead, the idea of the res publicae plays Tweedledum to the Tweedledee of private property, presupposing the private gains that induce people to go out and engage in trade. Intellectual achievements are not

57. Clifford Holderness, A Legal Foundation for Exchange, 14 J. LEGAL STUD. 321, 322-26 (1985).

58. Robert P. Merges, Contracting Into Liability Rules: Intellectual Property Rights and Collective Rights Organizations, 84 CAL. L. REV. 1293 (1996) (describing patent and copyright pools that lessen trading costs of intellectual property).

59. Michael A. Heller \& Rebecca S. Eisenberg, Can Patents Deter Innovation? ScI., May 1, 1998, at 698-99 (arguing that excessive patents can cause an "anticommons" blocking research access to the genome); Richard Stallman, Reevaluating Copyright: The Public Must Prevail, 75 OR. L. REV. 291, 29394 (1996) (arguing that the public has justifiably acquired the habit of copying). See also Carol M. Rose, The Several Futures of Property: Of Cyberspace and Folk Tales, Emission Trades and Ecosystems, 83 MinN. L. REV. 129, 154 (1998) (describing blockages as a species of "too much property") [hereinafter Rose, Several Futures].

60. See Wendy J. Gordon, Fair Use as Market Failure: A Structural and Economic Analysis of the Betamax Case and its Predecessors, 82 COLUM. L. REV. 1600, 1614-24 (1982). 
necessarily different; sometimes their creation and dissemination may depend on the inducements that property brings.

Thus, in the final analysis, the closest analogy to res publicae in intellectual space seems to be to the lanes and means of communication, rather than to the content of communication.

Having said that, however, it may be that the lanes of communication are not so easily separable from their content in Intellectual Space. This is most obvious with digital communication, where some form of copying is essential to communication itself. And this is true more generally in Intellectual Space; the intertextuality of creative endeavors means that, in Marshall McLuhan's famous phrase, the medium is the message. ${ }^{61}$ Here one cannot so easily designate content for private property, and communication lanes for res publicae.

Perhaps this is why, in Intellectual Space, res publicae has a primarily temporal character rather than a geographic one. One of the most interesting features of intellectual property law is that over the longer run, it does turn all once-propertized intellectual achievements into res publicae. I mentioned earlier that intellectual property functions to turn res communes, things that cannot be owned, into res nullius, things that are unowned but are capable of appropriation. At the end of the day, however, when the patent expires and the copyright runs out, the encapsulated creations do not become res nullius again, open for new appropriation under the laws of intellectual property. Instead they become res publicae, wide open to the public forever, by operation of law. They are now "prior art" or "public domain," never to be appropriated again under intellectual property law. Indeed, for this very reason, some inventors might prefer secrecy to patents. The sometimes-criticized liberality of the U.S. Patent Office might appear different in this light: A patent does assure that after the appointed length of time, inventions do indeed become open to the public for all time.

The underlying idea of this mixed regime, where private property and res publicae are segregated only temporally, seems to be a differential weighting over time of the relative importance of investment on the one hand and synergies on the other. Inducements to invest weigh more heavily at the outset, but the synergies of free availability and free use weigh more heavily later on. Again, from the perspective of an outsider, it seems that this balance between early private property and later res publicae could be the subject of a very central debate in intellectual property law. The balance would mean that the questions of duration of rights are critical to intellectual property law. ${ }^{62}$ It could also mean that private contractual circumventions of the legal time periods for intellectual property rights-the "shrink-wrap" contracts, the "rights management containers," and the statutes that protect such devices-are

61. See Marshall Mcluhan, Understanding Media 7-21 (1964).

62. See, e.g., Jonathan Zittrain, The Un-Microsoft Un-Remedy: Law Can Prevent the Problem That It Can't Patch Later, 31 CONN. L. REV. 1361, 1373 (1999) (proposing a five- or ten-year limit on software copyright). 
matters of even more critical importance..$^{63}$ If the private property and res publicae components of intellectual property are indeed temporal, then these questions of time are the very fulcrum of the balance between the two.

All this leads to a further question: Are private property and public access the only possibilities? Are there instances in which investment incentives and intertextual synergies might be quite differently organized, coming out somewhere between the public domain and exclusive private property? A good deal of intellectual property scholarship suggests that this is indeed the case, and that much creative effort actually takes place within property regimes that are neither entirely exclusive nor completely open to the public. ${ }^{64}$

Readers by now should not be surprised to find that there is a Roman law category for such mixed types of property, though the category has certain limitations:

\section{$\mathrm{V}$ \\ Res universitatis: PROPERTy Belonging to A (Public) Group IN Its CORPORATE CAPACITY}

The standard "owner" for the Roman res universitatis was a municipality, and its belongings were such public facilities as theaters and race-courses; but both private and public groups could own property in common, including lands or other income-producing property. ${ }^{65}$ The chief limitation on res universitatis in Roman times was that, at least in theory, the relevant corporate bodies required the authorization of the state. Nevertheless, in post-Roman times, medieval and early modern central states were weak indeed, and their lacunae were filled with countless groups that had their own properties and that often enjoyed semi-governmental authority. Such corporate bodies included guilds, monasteries, merchant groups, common field communities, and so on. In a continuation of their practices, a corporate body even governed New York City in its early days, largely managing the city through judicious use of the corporate property. ${ }^{66}$ Interestingly enough, universitatis gave its name to the modern "university," which in medieval times was a corporate body of students and teachers dedicated to education. ${ }^{67}$

63. Ryan, supra note 30, at 667-74 (criticizing extensions of time, rights-management containers, and statutory protections of these limitations on use of digital works).

64. For a summary of some of this scholarship and some of the issues, see Rose, Several Futures, supra note 59 , at $155-62$.

65. William L. Burdick, The PRinciples of Roman LAW AND THEIR Relation to MODERN LAW, 280-88 (Wm. W. Gaunt 1989) (1938).

66. See Hendrik Hartog, Public Property and Private Power: The Corporation of THE CITY OF NEW YORK IN AMERICAN LAW, 1730-1870, at 32-68 (1983) (describing New York's governance through property). Hartzog's picture of New York is similar to early modern European "cogoverning" corporate groups. See Carol M. Rose, Public Property, Old and New, 79 Nw. U. L. REV. 216, 218-222 (1984).

67. BURDICK, supra note 65 , at 283. 
Given the widespread and long-lasting character of group-based, limited common property regimes in Tangible Space, it is all the more interesting that these very important forms of resource management have been so widely overlooked in modern economic thinking about the commons, at least until recently. Elinor Ostrom is one of the chief scholars who has changed that pattern, and as she and her colleagues point out, there is no reason to think that the only forms of resource governance must come from individual ownership on the one hand, or from central governmental management on the other. She and others have found numerous examples of informal group property of "common-pool resources" far beyond Europe, from irrigating communities in the Philippines, to livestock-raising communities in Japan, to fishing communities in Turkey. ${ }^{68}$ Such communities clearly refute the idea that the commons is necessarily "tragic"; on the contrary, a number of these limited common property regimes have lasted in Tangible Space for centuries.

Such limited common property regimes may be commons on the inside, but they are property on the outside, that is, vis-a-vis non-members. ${ }^{69}$ But why have such regimes at all? They typically exist where a resource is too large for individual ownership, but still sufficiently bounded that its exploitation is amenable to joint management by a limited group. In a sense, res universitatis is a bounded form of res publicae, lending the advantages of interaction and cooperative joint management to a resource that is ultimately finite, as exclusively held property is. Because such common property regimes are more limited in membership than the public at large, they may generate a quite dense set of norms and customary practices-much more so than on the wide open transport lanes of res publicae. These customary practices in turn can help to limit overuse of the common resource and prod the members to invest in the common infrastructure-for example, a fishing community may work out elaborate means of taking turns with nets, or a set of irrigating communities along a river may devise rewards and punishments that induce individual farmers to maintain their shares of the common channels.

Are there analogs to res universitatis in Intellectual Space, where there is little or no need to police resource decimation or to maintain a physical infrastructure? Robert Merges has argued that there are, though he does not use the Roman law name. ${ }^{70} \mathrm{He}$ argues that researchers are often quite willing to share information and ideas with others in the same intellectual pursuits, and that they enjoy substantial creative synergies thereby; but he also argues that they are very unwilling to share these same ideas with commercial entrepreneurs or others in the world at large, perhaps in part because of the lack of reciprocity. And scientists are not the only ones; the Internet has

68. Elinor Ostrom, Governing the Commons: The Evolution of Institutions for COLleCtive ACTION 18-21, 65-69, 82-88 (1990).

69. Rose, Several Futures, supra note 59, at 144.

70. Robert P. Merges, Property Rights Theory and the Commons: The Case of Scientific Research, 13 Soc. PHIL. \& POL'Y 145 (1996); see also Merges, supra note 58, at 1293-1330, 1355-58 (using Ostrom's work to support contractual regimes for common use of intellectual properties). 
generated a considerable amount of collaborative creativity, from story trees to Chain Art. ${ }^{71}$ But these collaborative efforts are not simply wide open; Internet groups have also developed methods for excluding disruptive interlopers.

Might such groups mesh together to turn res universitatis into res publicae, common spaces open to all who are interested? Ostrom's work on limited common properties has described the "nesting" of smaller common properties into larger scale non-state governance regimes, for example, in irrigation, ${ }^{72}$ and her and Charlotte Hess' contribution to this symposium discusses similarly expanding networks for sharing digitized information. ${ }^{73}$

One might note, however, that such groups appear to move away from informal norms and instead to adopt self-conscious and detailed governance rules, making them less akin to norm-governed communities and rather more like the trade associations that Lisa Bernstein has so interestingly analyzed. ${ }^{74}$ Indeed, this self-consciousness may be a good thing from the perspective of democratic governance. Tangible Space certainly presents a warning about common regimes governed only by custom and community norms: Their norms can be hierarchical, xenophobic, and backward-looking, to the point that some critics say that we need to theorize a more "liberal commons" that is organized under the auspices of more democratic laws. ${ }^{75}$ Intellectual Space is not immune from these problems. Customary norms in the literary community, for example, have been notoriously inhospitable to women, even well into the twentieth century, and scientific communities too have sometimes been equally and unjustifiably dismissive of outsiders. ${ }^{76}$

In whatever ways creative communities may be organized, the point remains that in many intellectual and artistic endeavors, creativity may be synergistic less with the world at large than with communities of other artists, creators, and contributors. The university itself, sharing its root with the res universitatis, gives perhaps the quintessential example of the phenomenon: Creativity is exponentially enhanced by the free flow of ideas within a scholarly community. Here too there are opportunists, charlatans and zealots-and to some degree commercial users-who can disrupt the process, and thus universities try to

71. Chon, supra note 47 , at 274 .

72. OSTROM, supra note 68, at 101-02.

73. Charlotte Hess \& Elinor Ostrom, Ideas, Artifacts, and Facilities: Information as a CommonPool Resource, 66 LAW \& CONTEMP. PROBS. 111 (Winter/Spring 2003).

74. See Lisa E. Bernstein, The Questionable Empirical Basis of Article 2's Incorporation Strategy: A Preliminary Study, 66 U. CHI. L. REV. 710, 717-46 (1999) (analyzing trade rules of the National Hay Association, the National Feed \& Grain Association, the textile industry rules, and others).

75. Hanoch Dagan \& Michael Heller, The Liberal Commons, 110 YALE L. J. 549, 566 (2001); Carol M. Rose, Left Brain, Right Brain and History in the New Law and Economics of Property, 79 OR. L. REV. 479, 484-87 (2000).

76. See generally MARY ElLMAN, THINKING ABOUT WOMEN (1968) (very wittily discussing the pattern of dismissiveness and condescension to women authors); EVELYN FOX KELLER, A FEELING FOR THE ORGANISM: THE LIFE AND WORK OF BARBARA MCCLINTOCK (1983) (describing the life of a neglected biologist); DAva Sobel, Longitude: The True STORY OF A LONE GeniUs Who SOLVED THE GREATEST SCIENTIFIC PROBLEM OF HIS TIME (1995) (describing impediments to inventors outside scientific establishment). 
keep them out of bounds, albeit sometimes very clumsily, through such measures as peer review.

Community-based creative products that emerge from less developed countries have often been depicted in intellectual property law as unowned things; thus folklore, religious artifacts, and agricultural strains are sometimes treated as res nullius, open to appropriation by others, because they were not created by a single "romantic" artist or adventurer. If this is true, however, then the same might also be said of the products of the Globe Theater or the Fermi Labs, since so much creative work mixes individual contributions with ideas that are "in the air" of the creative community. Citizens of less developed countries, faced with the argument that their artworks and agricultural products are "the common heritage of mankind," might instead hear an echo of the Romans' view that conquered territory was res nullius. Better that we devise ways to think of these endeavors as res universitatis, so that these communities of creators too can enjoy their fruits.

Res universitatis, then, is a type of property that is non-exclusive but also bounded. For intellectual matters, res universitatis is a rubric that does acknowledge the usefulness of property rights in creative accomplishments. But unlike individual intellectual property, res universitatis focuses attention, first, on encouraging the group interactions that greatly foster creativity, and second, on policing the boundary of behaviors that are disruptive to creative groups. Perhaps not much more is needed, given the capacity of limited groups to generate their own norms. Once again from an outsider's perspective on intellectual property, it appears that this limited community aspect of Intellectual Space is rather underdeveloped in the law, as it has been until recently in Tangible Space.

Going back to trace the life cycle of intellectual property, then, we might find that intellectual matters begin as res communes (things incapable of ownership), whereupon intellectual property law turns them into a kind of legal res nullius (things open to appropriation); but they may well become res universitatis (things belonging to creative communities) on their way to the final wide-open synergies of the legally protected res publicae - things open to all by operation of law, the public domain that reigns after property protection expires.

I cannot leave the Romans, however, without mentioning one concluding type of nonexclusive property:

VI

\section{RES DIVINI JURIS: THINGS THAT ARE UNOWNED BY ANY HUMAN BEING BECAUSE THEY ARE SACRED, HOLY OR RELIGIOUS ${ }^{77}$}

The things classed under this rubric in Roman law-temples, tombs, religious statuary-were considered to belong to no one because they were

77. BURDICK, supra note 65, at 308-309; HUNTER, supra note 13, at 66. 
dedicated to the service of the gods, or because an offense to them was considered to be offensive to the gods. ${ }^{78}$ Such things were a class of res nullius because although they are physically capable of appropriation, they are still unowned; the impediment to propertization is not natural but divine.

I must confess that I once thought there were no real analogs to this kind of property in the tangible public property of modern secular countries, but I now think I was mistaken. At least in the United States, the great wilderness parks, deserts and seashores, with their sense of the sublime and the vast, may in some ways fill the role of res divini juris. Such places suggest to the visitor the majesty of creation, the vastness of space, the untamed-ness of something outside human capacity to grasp. If there is a role for res divini juris as tangible public property in our modern jurisprudence, surely this is one place where it resides.

Of course, it is physically possible to cut down trees in such places or to drill for oil in them or to race around in noisy, wide-tire vehicles, but the argument against such behavior is chiefly one that sounds in the quasi-religious terms of travesty and sacrilege: Such lands should be open to all, but each visitor should treat them with the appropriate attitude of awe. No bolt from heaven, however, strikes down the logger, the oil well-driller, or the dune-buggy driver. The divine wildness of the wide-open spaces is in the end metaphoric; the organized public, after all, has to protect them and invest in them if these spaces are to last. $^{79}$

There is clearly also an analog for the res divini juris in the intellectual world as well. It is the canon, the classics, the ancient works whose long life has contributed to their status as rare, extraordinary-and also a little wild, never quite capable of complete domestication even by the most erudite pedant. And lest we forget that all things godlike may be accompanied by lesser gods (or even false ones) and their representations, we might wish to include here too the iconography of modern commercial culture, the Mickeys and Minnies and Scarletts. To be sure, such symbolic creations might well deserve the protection of private ownership until the time they actually become iconic. But thereafter, though the point is controversial, the category of res divini juris could well embrace this iconography and dedicate it at least in some measure to the public, as in copyright law's exception for parody. ${ }^{80}$ Why? Precisely because the

78. In a somewhat odd wrinkle, this included climbing over the city walls, which was an offense punishable by death, because one was supposed to enter and exit the city by the gates. BURDICK, supra note 65 , at 309.

79. For an appropriately named commentary, see Joseph Sax, Helpless Giants: The National Parks and the Regulation of Private Lands, 75 MICH. L. REV. 239 (1976) (primarily describing external threats to the parks); $c f$. Alston Chase, Playing God at Yellowstone: The Destruction of AMERICA'S FIRST NATIONAL PARK (1987) (detailing mismanagement by the Park Service itself).

80. A somewhat similar note is sounded in the law of historic preservation about tangible things; some buildings seem to become "public" or at least subject to public constraint by operation of the passage of time and by the public's embrace of them-including some quite odd buildings that the public grows to like. See Carol M. Rose, Preservation and Community: New Directions in the Law of Historic Preservation, 33 STAN. L. REV. 473, 497, 497 n.110 (1981). 
continuing reconsideration and reworking of the icons is so enormously productive of new cultural insights. And of course, because it is fun. ${ }^{81}$ After all, even the comic gods need to be served. ${ }^{82}$

Notice that unlike the tangible res divini juris, the canon (and even the iconography) does not really need much public protection; we can generally rely on the devotees, imitators and satirists to keep these works in the public eye unless they grow terminally old and tired. Indeed, one of the functions that the public domain serves is to open would-be classics to the withering fires of ridicule and repetition, thus vividly demonstrating which can withstand these tests of mockery and cliché. Almost by definition, there is little that can destroy the true gods of the canon, however much they may suffer periodic temporal eclipses and satiric insult. Bach has survived the Swingle Singers and the Moog machine. That is why Bach is Bach. The Mona Lisa survives her cartoon picture on the Chunky Beef Soup can. If anything, she is all the more enigmatic for it. Bach can eat the Swingle Singers for breakfast, the Mona Lisa can eat Chunky Beef Soup for lunch. It remains to be seen what Mickey can survive.

81. For a recent case of the parody example, see the controversies over the 2001 publication of The Wind Done Gone by Alice Randall. SunTrust Bank v. Houghton Mifflin Co., 268 F.3d 1257 (11th Cir. 2001) (reversing preliminary injunction against new novel on the ground that Gone With the Wind author Margaret Mitchell's estate had not shown a likelihood of prevailing on merits, particularly "fair use" as parody). See also Bill Rankin, Mitchell Estate to Continue "Gone" Battle, ATLANTA J. \& CONS., Oct. 12, 2001 at 3E (reporting 11th Circuit victory for parodist, which gave the Mitchell estate the resolve to pursue the suit).

82. See Robert M. Polhemus, Comic Faith: The Great Comic Tradition from Austen TO JOYCE, 3-9 (1980) (arguing that comedy is linked to religious sensibility). 